\title{
Collaboration of Business Intelligence and Cloud Computing and Selecting the Best Cloud Business Intelligence Solution*
}

İpek ASLAN, Yeditepe University, Institute of Social Sciences, ipek.esen@std.yeditepe.edu.tr, (D) 0000-0001-6524-6499

Aşkın DEMİRAĞ, Yeditepe University, Faculty of Commerce, Associate Prof., ademirag@yeditepe.edu.tr, (DD 0000-0001-7868-0438

Erkut AKKARTAL, Yeditepe University, Faculty of Commerce, Assoc. Prof., erkut.akkartal@yeditepe.edu.tr, (D) 0000-0002-7090-4449

\begin{abstract}
In this study, business intelligence concept and architecture were explained from data sources to reporting with many advantages provided to institutions in the first part. Then, both cloud computing technology with its service and deployment models and the characteristics of cloud computing experienced clarified in the second part of the study. The relationship between cloud computing and business intelligence and the concept arisen from this collaboration, cloud business intelligence, were represented with its benefits and obstacles experienced by companies using this technology in the third part. Four service providers as alternatives serving cloud business intelligence solutions were selected and the criteria were determined according to the needs of the company, that would like to use a cloud business intelligence software. After all the criteria are prioritized and the alternatives are determined, the best software was chosen by using the Analytic Hierarchical Process software, called Expert Choice.
\end{abstract}

Keywords : Business Intelligence, Cloud Computing, Cloud Business Intelligence

\section{İș Zekâsı ve Bulut Bilișim İşbirliği ve En İyi Bulut İs Zekâsı Çözümü Seçimi} $\ddot{O Z Z}$

Bu çalı̧̧mada iş zekâsı konsepti ve mimarisi, veri kaynaklarından raporlama aşamasına kadar kurumlara sağladığı faydalar ile birlikte açıklanmıştır. Ardından hem bulut bilişim teknolojisi geliştirme ve servis modelleri hem de tecrübe edilen bulut bilişim özellikleri incelenmiştir. Bulut bilişim, iş zekâsı ve bu terimlerin birlikteliğinden doğan bulut iş zekâst terimi, bu konsepti uygulayan şirketler tarafından tecrübe edilen faydaları ve aksak yönleriyle anlatılmıştır. Bulut iş zekâsı alanında hizmet veren dört servis sağlayıcı seçildi ve bulut tabanlı iş zekâsı yazılımı

\footnotetext{
* This study is derived from the master's thesis titled "Collaboration of Business Intelligence and Cloud Computing and Selecting the Best Cloud Business Intelligence Solution" conducted under the supervision of Aşkın DEMIRAĞ at Yeditepe University, Institute of Social Sciences.
} 
kullanmak isteyen şirketimizin ihtiyacına göre kriterler belirlenmiştir. Bütün kriterler önceliklerine göre stralandiktan ve alternatifler belirlendikten sonra karar vermek için "Expert Choice" adlı Analitik Hiyerarşi Süreci yazılımı kullanılarak şirket için en uygun olan bulut iş zekâsı yazılımı seçilmiştir.

Anahtar : : işs Zekâsı, Bulut Bilişim, Bulut iş̧ Zekâsı

\section{Kelimeler}

\section{INTRODUCTION}

In today's world a huge quantity of data is produced every passing second. Most organizations realize the necessity of using this data as efficient as possible in order to gain competitive advantage by making both strategic and tactical decisions. Trying to make decisions based on just recording and making basic reports is not enough in order to even survive any more. The organizations expect to extend their marketplace need to record thousands of transactions, process data and make detailed and complex analysis, so the significance of data is increasing day by day. Data can be analyzed, customized, and visualized instantly thanks to business intelligence tools.

Cloud computing means using various services like software developments platforms, storage, software, and servers over the internet rather than a local server. Cloud technologies provide users an agile way to access business intelligence applications.

In this study, business intelligence and cloud computing concepts are explained in detail and advantages of using cloud computing for business intelligence are expressed in order to remove barriers in organizations' mind and enable them to understand benefits that will be gained from this association, which is called cloud business intelligence.

\section{BUSINESS INTELLIGENCE}

Increasing competition with the globalization in business world forces companies to make faster and more efficient decisions by processing raw data. In this stage businesses need more complex analysis and reporting tools. Business intelligence applications get involved in the process in order to serve this purpose.

The author, (Vercellis, 2009, p. 3) defined business intelligence (BI) "as a set of mathematical models and analysis methodologies that exploit the available data to generate information and knowledge useful for complex decision-making processes." BI creates value for organizations by using data or facts and increases capabilities of decision making for managerial processes like budgeting, planning and controlling. The fact-based decision making with the strong computer technology enable managers to direct in confidence. 


\subsection{Business Intelligence Architecture}

With the desire to enhance business value and succeed in its overall goal, many organizations search for new ways to obtain valuable insights from organizational data. Businesses can increase their insight-driven capabilities by investing the appropriate BI systems. In this way, they have more control over their data.

Data collected from different sources is extracted, transformed and load into a data warehouse. Then the data is analyzed by using BI tools and analytical models. Lastly, reports, insights, dashboards are distributed for decision making process.

\section{CLOUD COMPUTING}

In recent years most companies want to succeed in their business operations and corporate growth establish the necessary IT infrastructure and collect and process large amounts of data. However, if the system of the organization does not use shared resources, the data increasing incrementally day by day will be overwhelming. Cloud computing (CC) provides a solution for the need of a high-performance system with lower using cost.

The author (Furht \& Escalante, 2010, p. 3), defines cloud computing as follows:

"Cloud computing can be defined as a new style of computing in which dynamically scalable and often virtualized resources are provided as a services over the Internet. Cloud computing has become a significant technology trend, and many experts expect that cloud computing will reshape information technology (IT) processes and the IT marketplace."

\subsection{Characteristics of Cloud}

High scalability, multi-sharing, agility, high availability, and reliability can be described as the characteristics of cloud solutions. High scalability enables the use of resources for a large pool of users who have different needs. While the organizations can enjoy a high availability for their solutions, cloud infrastructure provides reliability continuously adapted to the user needs. The agility characteristic provides a very short response time. The multisharing is the main characteristic of cloud that enables users to share resources (Tole, 2014, p. $50)$.

\section{CLOUD BUSINESS INTELLIGENCE}

Business intelligence and cloud computing are the terms complementing each other. The infrastructure of cloud makes accessing to the business intelligence applications agile with any device restrictions. As time progressed, more data is available in the cloud as the number 
of organizations utilized from cloud is increasing day by day, so the popularity of Cloud BI or BI-as-a-service is multiplying.

The term, Cloud Business Intelligence (Cloud BI), is used to define the concept of delivering business intelligence capabilities as a service. In the competitive business world, managers need reliable and qualified insights driven by accurate data more than ever (AlAqrabi et al., 2020).

Cloud based business intelligence services are especially valuable when the user wants to access the data and analysis by using a smartphone or a tablet. Mobile BI provides data analysis in static reporting or interactive modes thanks to the capabilities of mobile devices such as natural language query, touchscreen, camera location awareness. It offers opportunities for targeting customers related to their current activities, and location as a part of broader interactive marketing campaign (DOMO, 2020).

\subsection{Selection of the Cloud BI Solution}

Every organization that wants to take advantage of the power of data should make detailed analysis based on their needs and objectives. Business intelligence solutions help organizations to transform the raw data to a meaningful information by making some analysis in order to shorten the process of decision making.

\subsubsection{Company Description}

As a scenario, we have a company, Sunorganic, established in Bodrum in Turkey that attaches a great importance to organic nutrition and life. The founder decided to establish the company for producing variety of soaps, balms, shampoos and detergents whose ingredients contain only organic herbal essences and oils.

\subsubsection{Need for BI Solution}

The company wants to grow business by managing the data and serving its customers in an efficient manner. It expects to predict customer behavior, so it can develop new marketing strategies, offer new products, or promote some products based on the customer transactions. It can reduce costs and increase sales by evaluating reports that provide gaining an insight. The operational data is stored in excel tables, but it will not be enough for making detailed analysis and getting an insight from it, so the founder decided to make an investment in business intelligence software. In order to take advantage of independence from the place and the platform at small expense provided by cloud technology, the company decided to use cloud-based business intelligence software. 


\subsubsection{Research Questions}

This research intends to select the best Cloud BI software by using multi-criteria decision making. In order to complete the project successfully many research questions need to be clarified, that will be comprehended at the end of the project, are shown in Table 1.

Table 1: Research Questions

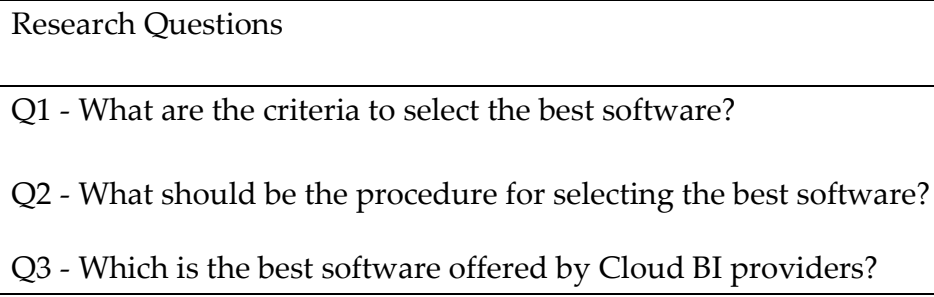

\subsubsection{Method \& Methodology}

One of the best suitable methodology for multi-criteria decision making is analytical hierarchy process (AHP), which will be used for this study as a valuable technique for choosing the best software among alternatives. It is extensively used in making complex decisions for many years. Analytical Hierarchy Process, developed by Thomas L. Saaty in 1970s, is a method for complex decision making where many variables are considered in the prioritization and selection of alternatives. An AHP process consists of three steps. It begins with structuring a problem that is decomposed into manageable sub-problems. That is, the objective is branched into a hierarchy of criteria. After the construction of logical hierarchy, the alternatives are assessed by making pair-wise comparisons for each selected criteria. In order to select the best solution for the company, the AHP (Analytic Hierarchy Process) software, "Expert Choice", will be used to produce an output for easy decision making.

\subsubsection{Determination of the Criteria and the Alternatives}

With the help of Magic Quadrant for Analytics and BI Platforms, published by Gartner, four BI solutions were selected as alternatives that serve in high standards including Tableau, SAP Analytics Cloud, Power BI, and IBM Cognos. They are the most successful software in business intelligence market for years.

Microsoft and Tableau are considered as leaders by a long way as illustrated in Figure 1. They are succesfull providers in terms of completeness of vision and ability to execute. SAP is also so popular in Turkey in recent years. SAP has been in collaboration with businesses from all levels. SAP analytics Cloud as solid and stable platform provides powerful, agile analytics with an effective security. IBM is also a long-established company carrying out 
activities accomplishedly for many years in Turkey. It is one of the most valuable and widely esteemed brands. It is selected as the 18th most innovative company by Fast Company which is a monthly American business magazine focusing on technology, business, and design (Fast Company, 2021).

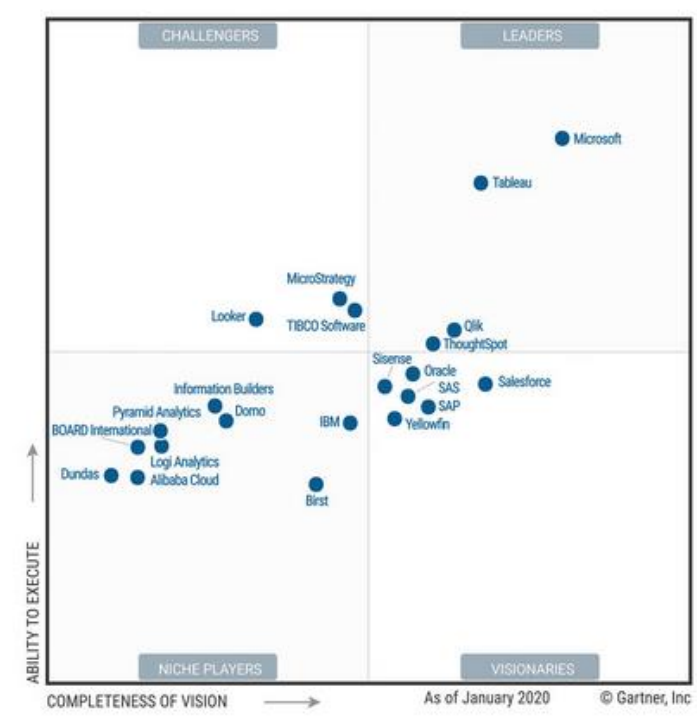

Figure 1: Gartner Magic Quadrant for Analytics and BI Platforms

Source: (Stellar Consulting, 2021)

\subsubsection{Prioritization of the Criteria}

Before prioritizing the criteria, I investigated the services in detail provided by BI software vendors. Capterra, the business reviews website is a valuable source for me whose members share their software experiences they used. This website whose reviews are verified provides scores for each criteria corresponds to each alternative. The real users of the software gave scores based on their satisfaction from the services of each product.

In order to prioritize the criteria, a survey was made. Points were given to each criteria by respondents, who are experts in information technology sector. The averages of the points are shown in Table 2.

Table 2: Averages of the Survey Points

\begin{tabular}{|l|l|}
\hline Criteria & Average Points \\
\hline Features \& Functionality & 91,8 \\
\hline Ease of Use & 70,8 \\
\hline Training \& Support & 70,6 \\
\hline Price & 69,0 \\
\hline Customer Service & 68,6 \\
\hline
\end{tabular}




\section{AJIT-e Bilişim Teknolojileri Online Dergisi \\ Academic Journal of Information Tecnology}

2021 Summer/Yaz - Cilt/Vol: 12 - Sayı/Issue: 46

doi) 10.5824/ajite.2021.03.002.x

Features \& functionality was selected as the most important criteria. As the main purpose of acquiring a BI solution is gaining more information from data, obtained from several analysis and other steps, and use this for decision making, the features have to be functional and practical as much as possible. The second one is -ease of use- which is necessary for the system to be user friendly. Training \& Support is the third, which has to be so helpful as the system is new and the users will need more help for understanding the technology and its usage. Price is the fourth one where customer service is the last.

\subsubsection{Comparing Relative Importance}

According to the prioritization, the values defined were placed in related fields in the AHP software in order to observe the relative importance between criteria as shown in Figure 2. "Features \& functionality" is the most important criteria where "ease of use" is on the second rank. The third one is "training \& support", and it is followed by "price" and "customer service". The points were given to these criteria based on the points given in the survey.

Figure 11, created in Expert Choice, indicates that "features \& functionality" is slightly more important than "ease of use". It is also strongly important than "price" which has approximately equal importance with "customer service".

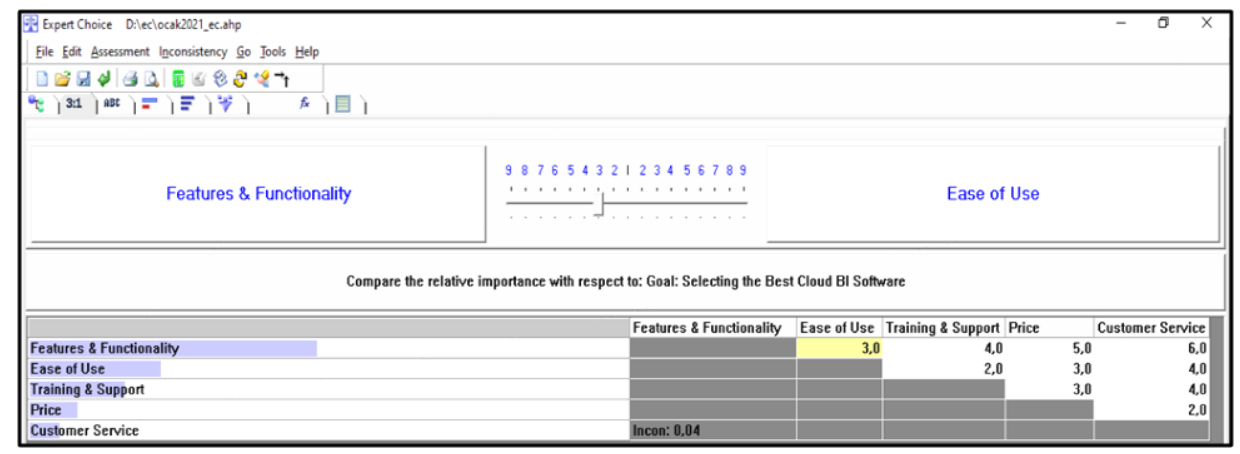

Figure 2: Relative Importance with Respect to Goal

\subsubsection{Criteria Information}

Making criteria information clear is necessary as the points will be placed in related cells according to this information.

- Features \& Functionality should be as good as possible.

- Customer Service should be as good as possible.

- Ease of use should be as much as possible.

- Price should be as low as possible.

- Support \& Training should be as good as possible. 


\subsubsection{Data Matrix}

The scores of three criteria including "features \& functionality", "ease of use" and "customer service" obtained from the Capterra (Capterra, 2020), business reviews website. The criteria of "training \& support" was scored in accordance with the quality and the diversity of the services provided by alternatives and the "prices" were obtained from the official web sites of each provider. All scores are illustrated in Table 3.

Table 3: Data Matrix

\begin{tabular}{|l|l|l|l|l|}
\hline & Tableau & $\begin{array}{l}\text { Power BI } \\
\text { Pro }\end{array}$ & $\begin{array}{l}\text { IBM } \\
\text { Cognos }\end{array}$ & $\begin{array}{l}\text { SAP Analytics } \\
\text { Cloud }\end{array}$ \\
\hline Features \& Functionality & 4,5 & 4,4 & 4,1 & 4 \\
\hline Training \& support & 4,5 & 3,5 & 4,5 & 4 \\
\hline Customer Service & 4,2 & 4,1 & 3,7 & 4,2 \\
\hline Ease of Use & 4 & 4 & 3,8 & 3,8 \\
\hline Price(dollar/month) & 70 & 9,99 & 40 & 35,4 \\
\hline
\end{tabular}

\subsubsection{Features \& Functionality Matrix}

According to the reviews, data related to "features \& functionality" of selected providers are shown in Table 4.

Table 4: Points for Features \& Functionality

\begin{tabular}{|l|l|l|l|l|}
\hline \multirow{2}{*}{$\begin{array}{l}\text { Features } \\
\text { Functionality }\end{array}$} & Tableau & Power BI Pro & IBM & SAP \\
\cline { 2 - 5 } & 4,5 & 4,4 & 4,1 & 4 \\
\hline
\end{tabular}

When the data is evaluated, Tableau is 1,02 times more advantageous than Power BI. Tableau is also 1,09 times more functional than SAP. The value of inconsistency ratio should be smaller than 0,1 , therefore there is no conflict in comparing criteria between each other as the ratio is 0 as shown in Figure 3.

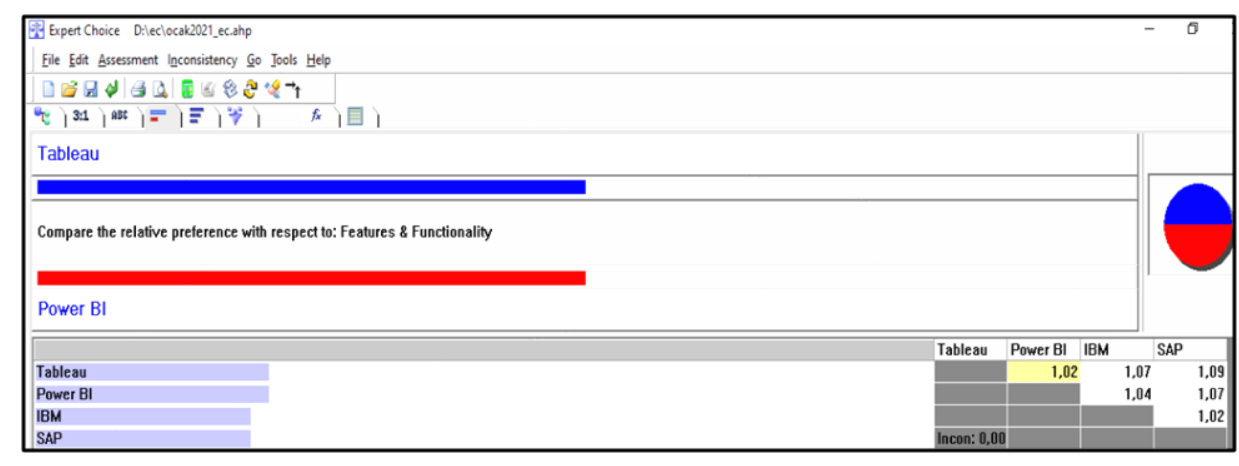

Figure 3: Relative Importance with Respect to Features \& Functionality 


\section{AJIT-e Bilişim Teknolojileri Online Dergisi \\ Academic Journal of Information Tecnology}

2021 Summer/Yaz - Cilt/Vol: 12 - Sayı/Issue: 46

doi) 10.5824/ajite.2021.03.002.x

\subsubsection{Training \& Support Matrix}

According to the training facilities illustrated in Table 5, as Tableau, SAP and IBM provide almost the same capabilities, they get 4 points as none of them is perfect. As documentation and webinars are not enough for the company in order to train the users, Power BI had 3 points.

Table 5: Training \& Support Services of the Providers

\begin{tabular}{|l|l|l|l|l|}
\hline & IBM Cognos & Power BI Pro & $\begin{array}{l}\text { SAP Analytics } \\
\text { Cloud }\end{array}$ & Tableau \\
\hline Training & $\begin{array}{l}\text { Documentation } \\
\text { In person } \\
\text { Webinars }\end{array}$ & $\begin{array}{l}\text { Documentation } \\
\text { Webinars }\end{array}$ & $\begin{array}{l}\text { Documentation } \\
\text { Webinars } \\
\text { Live online }\end{array}$ & $\begin{array}{l}\text { Live online } \\
\text { In person }\end{array}$ \\
\hline Support & $24 / 7$ (live rep) & $\begin{array}{l}\text { Business Hours } \\
\text { Online }\end{array}$ & $\begin{array}{l}\text { Business Hours } \\
\text { Online }\end{array}$ & $\begin{array}{l}7 / 24 \quad \text { (live } \\
\text { rep) } \\
\text { Online }\end{array}$ \\
\hline
\end{tabular}

As for the support of providers, IBM Cognos and Tableau took advantage of its 24/7 service, so they had 5 points while 4 points were given to others. Calculating the average of the points given to training and support individually for each provider gives us the values for the criteria of "training \& support", which are shown in Table 6.

Table 6: Points for Training \& Support

\begin{tabular}{|l|l|l|l|l|}
\hline \multirow{2}{*}{ Training \& Support } & Tableau & Power BI Pro & IBM & SAP \\
\cline { 2 - 5 } & 4,5 & 3,5 & 4,5 & 4 \\
\hline
\end{tabular}

As indicated in the Figure 4, Tableau is 1,28 times more advantageous than Power BI, whose ratio is calculated by dividing 4,5 to 3,5 . Tableau and IBM offer the same satisfaction in terms of "training \& support", which is 1,12 times more preferable than SAP.

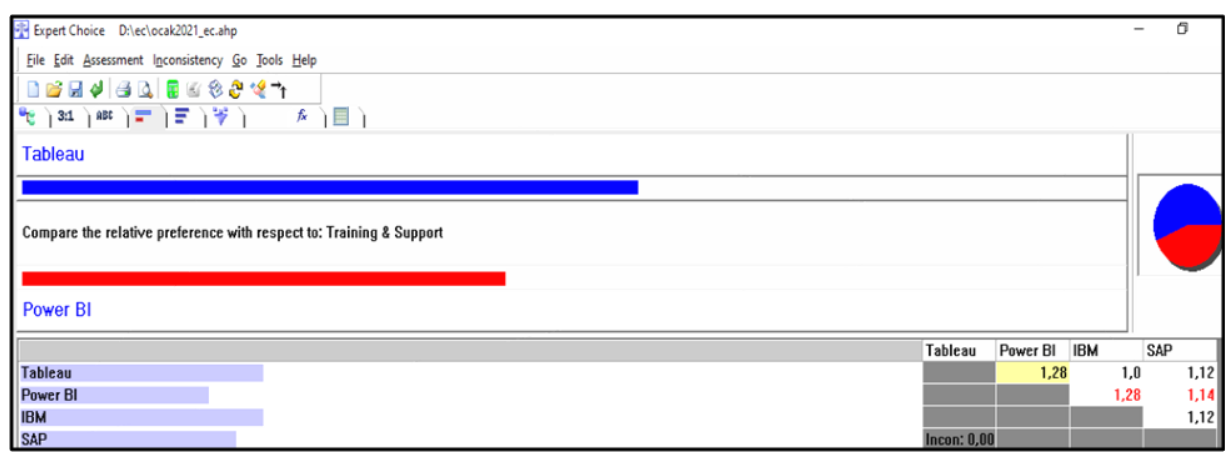

Figure 4: Relative Importance with Respect to Training \& Support 


\subsubsection{Customer Service Matrix}

The values of customer service as shown in Table 7 were placed into the corresponding cells in the AHP software.

Table 7: Points for Customer Service

\begin{tabular}{|l|l|l|l|l|}
\hline \multirow{3}{*}{ Customer Service } & Tableau & Power BI Pro & IBM & SAP \\
\cline { 2 - 5 } & 4,2 & 4,1 & 3,7 & 4,2 \\
\hline
\end{tabular}

Tableau has 1,02 times better customer service than Power BI whereas Tableau and SAP serve the same customer service quality. Power BI is 1,1 times more advantageous than IBM while SAP offers 1,02 times more satisfying service than Power BI. Lastly, SAP provides 1,13 times superior customer experience than IBM as illustrated in Figure 5.

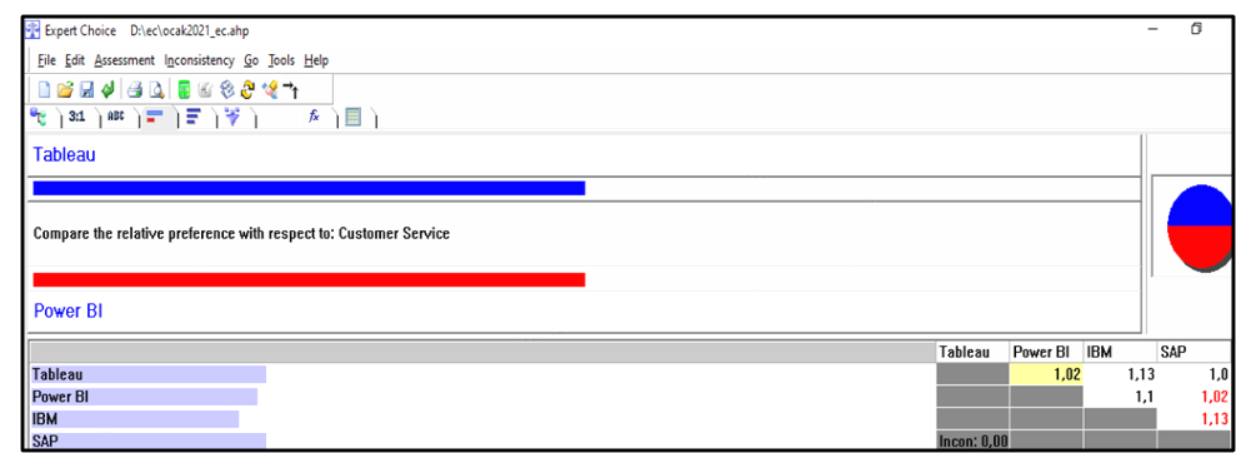

Figure 5: Relative Importance with Respect to Customer Service

\subsubsection{Ease Of Use Matrix}

According to the real customers' reviews, the points related to ease of use for each provider are shown in Table 8.

Table 8: Points for Ease of Use

\begin{tabular}{|l|l|l|l|l|}
\hline \multirow{2}{*}{ Ease of Use } & Tableau & Power BI Pro & IBM & SAP \\
\cline { 2 - 5 } & 4 & 4 & 3,8 & 3,8 \\
\hline
\end{tabular}

When the data in Figure 6 is evaluated, Tableau and Power BI serve in the same manner in terms of "ease of use". Tableau and Power BI are 1,05 times more advantageous than IBM and SAP. IBM and SAP offer the same quality of service that is worse than Tableau and Power BI. 


\section{AJIT-e Bilişim Teknolojileri Online Dergisi \\ Academic Journal of Information Tecnology}

2021 Summer/Yaz - Cilt/Vol: 12 - Sayı/Issue: 46

doi) 10.5824/ajite.2021.03.002.x

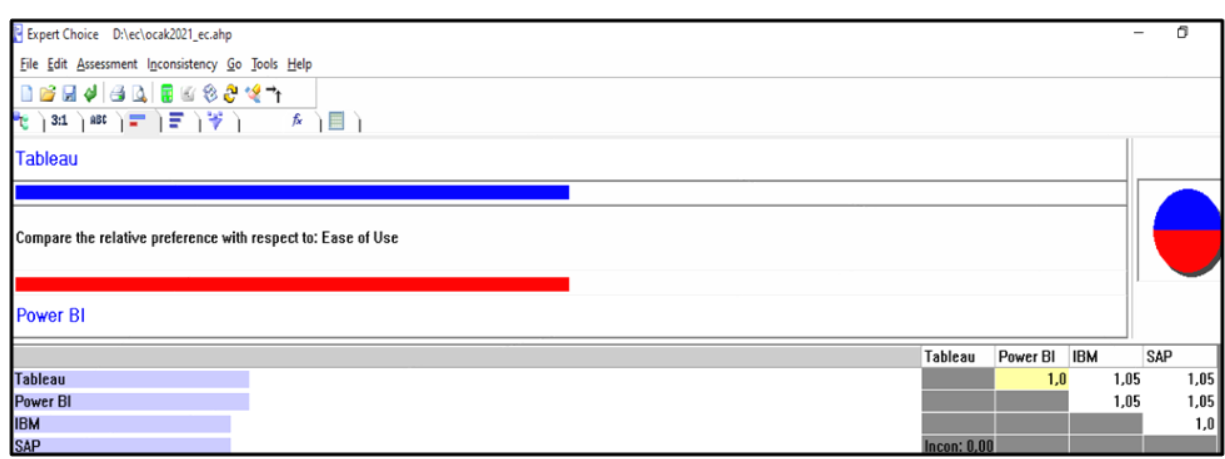

Figure 6: Relative Importance with Respect to Ease of Use

\subsubsection{Price Matrix}

The prices shown in Table 9 obtained from the providers' official web sites. They demand different prices for their cloud based BI solutions on a monthly basis. Tableau charges 70 dollars per user monthly (Tableau, 2020) whereas Power BI requests 9,99 dollars per user monthly (Microsoft Power BI, 2020).

IBM Cognos charges 40 dollars per user for a month (IBM, 2020) while SAP charges 30 euro per user monthly that corresponds to 35,4 dollar (SAP, 2020).

Table 9: The Prices of the Software Providers

\begin{tabular}{|l|l|l|l|l|}
\hline \multirow{2}{*}{ Price (dollar) } & Tableau & Power BI Pro & IBM & SAP \\
\cline { 2 - 5 } & 70 & 9,99 & 40 & 35,4 \\
\hline
\end{tabular}

When interpreted the Figure 7, Power BI is 7 times more profitable than Tableau. IBM is 1,75 times more economical than Tableau while SAP charges 1,97 times lower price than Tableau demands.

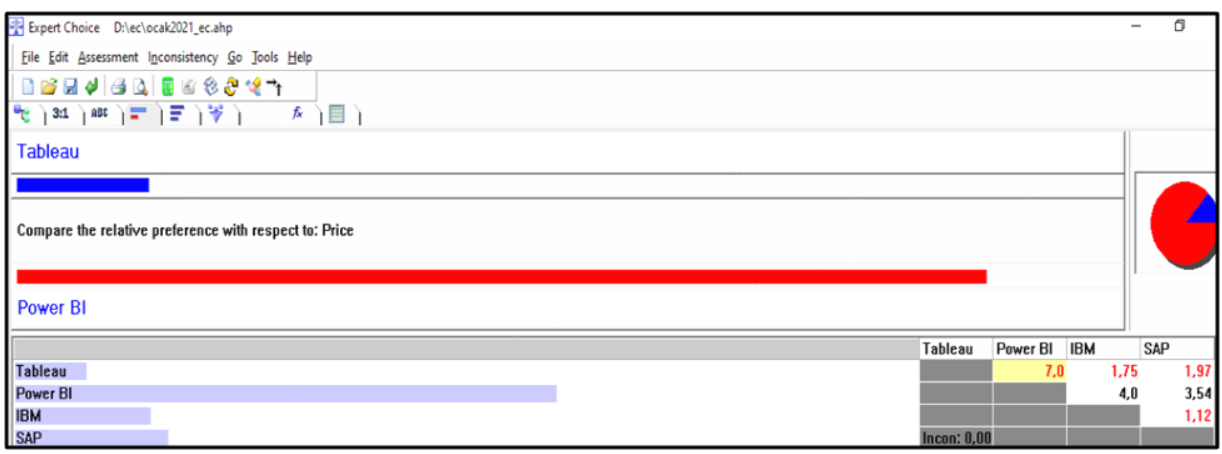

Figure 7: Relative Importance with Respect to Price

\subsubsection{Synthesis the Results}


When the results are synthesized with respect to the goal, the percentages of each alternative shown in Figure 8 were produced. According to the output, the company should select the product of Power BI with the $26,1 \%$. It is the most appropriate software in terms of the criteria prioritized by the company including features \& functionality, training \& support, customer service, ease of use and price.

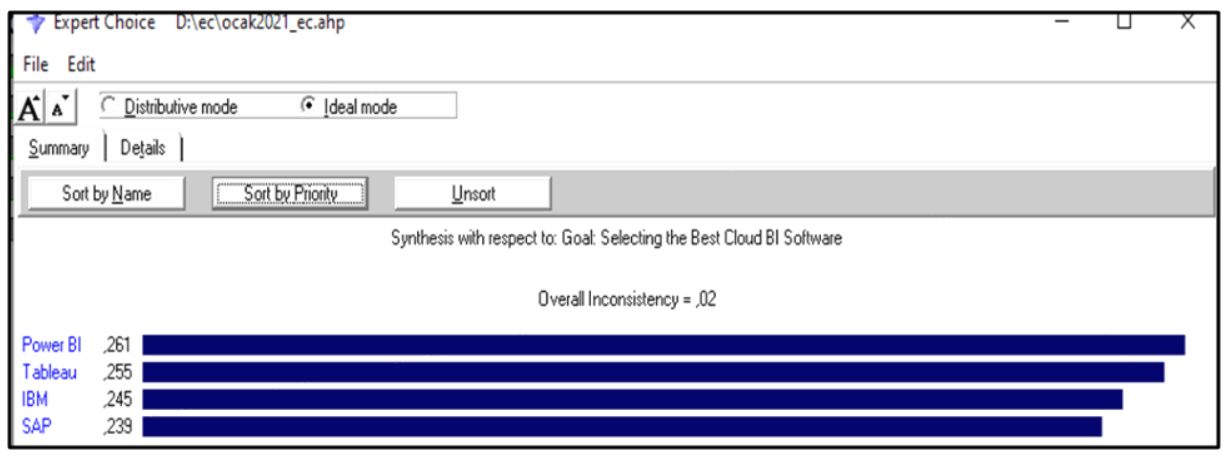

Figure 8: Synthesis the Result with Respect to Goal

Figure 9 shows the dynamic sensitivity for nodes, which shows the criteria, ordered by priorities on the left side, and the alternatives on the right side. If the weights of the criteria change, the result will also change.

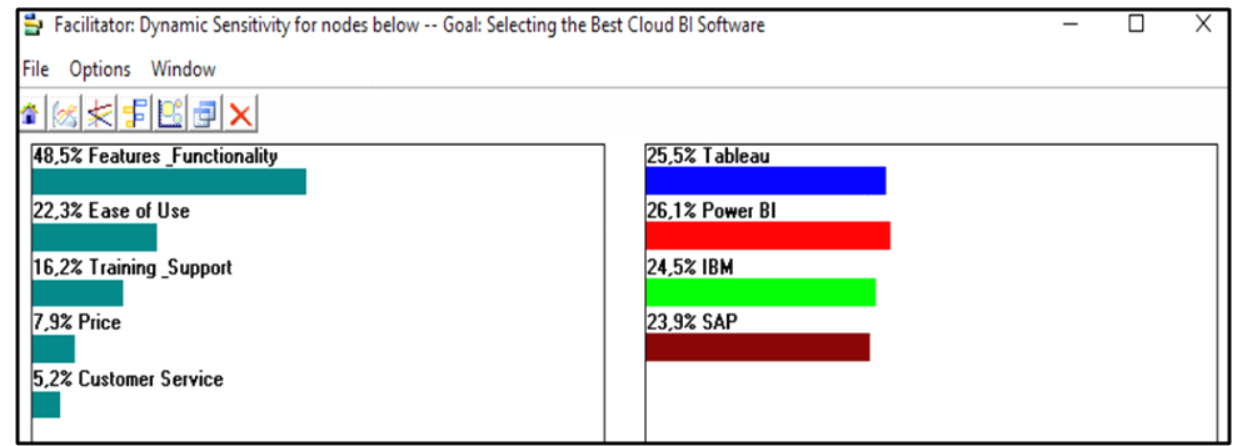

Figure 9: Dynamic Sensitivity for Nodes

"Features and functionality" is the criteria which has the greatest importance among other alternatives at present, but if the company still wants to increase the weight of the criteria much more, the result will remain the same as illustrated in Figure 10. 


\section{AJIT-e Bilişim Teknolojileri Online Dergisi \\ Academic Journal of Information Tecnology}

2021 Summer/Yaz - Cilt/Vol: 12 - Sayı/Issue: 46

doi) 10.5824/ajite.2021.03.002.x

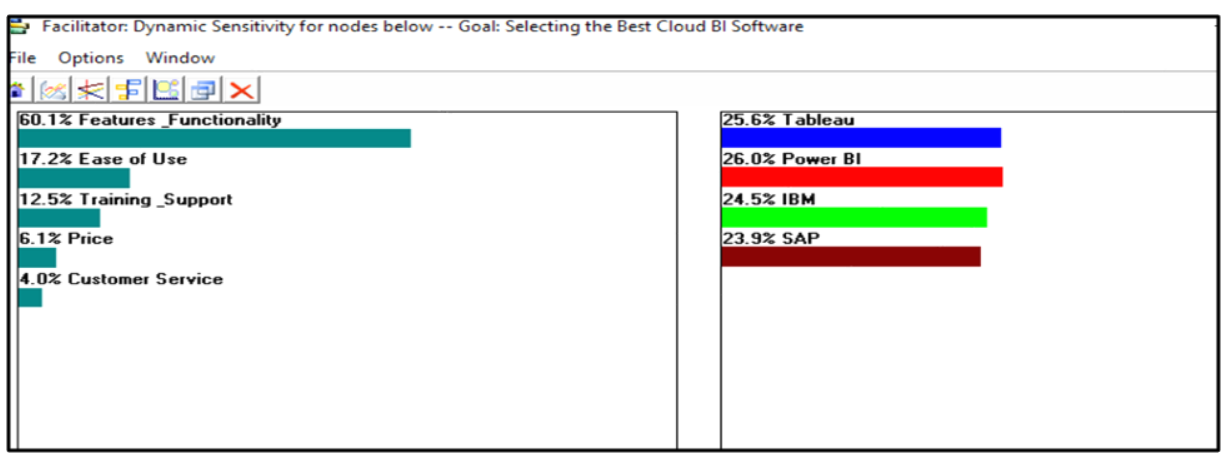

Figure 10: Dynamic Sensitivity with High Priority of Features and Functionality

If the need of "ease of use" becomes significant, when the weight for "ease of use" is increased considerably, the result will not change. Power BI will remain as the most appropriate alternative as illustrated in Figure 11.

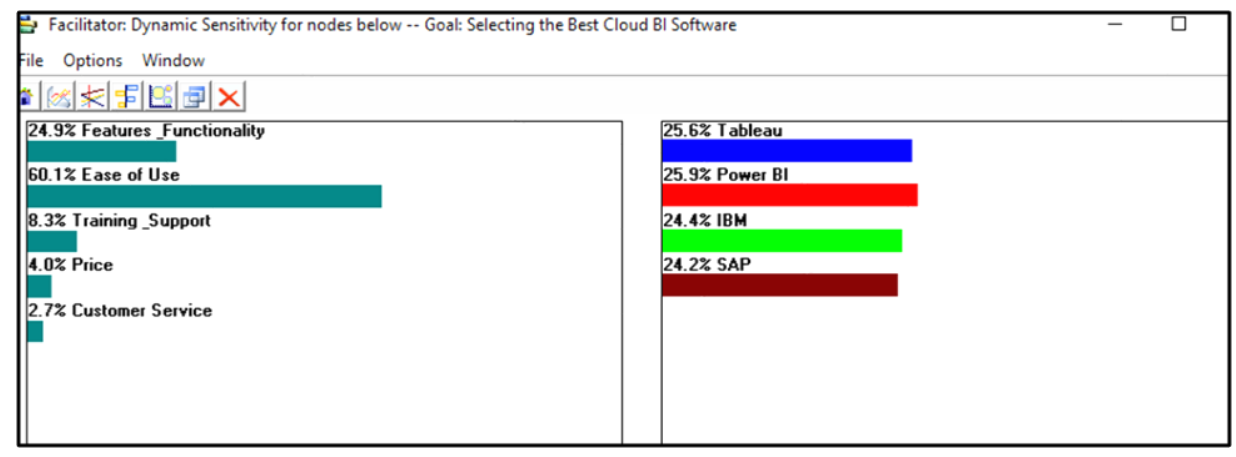

Figure 11: Dynamic Sensitivity with High Priority of Ease of Use

If "features and functionality" offered by all providers satisfy the needs, "training \& support" may be the most important criteria for the firm, so it can see the new result by only pulling the "training \& support" bar as much as it wants. When the priority given to "training \& support" is increased, Tableau will be the winner as shown in Figure 12.

\begin{tabular}{|l|l|}
\hline File Options Window & - \\
\hline $31,0 \%$ Features_Functionality & \\
\hline $14,3 \%$ Ease of Use & $26,1 \%$ Tableau \\
\hline $46,3 \%$ Training_Support & $24,4 \%$ Power BI \\
\hline $5,0 \%$ Price & $25,5 \%$ IBM \\
\hline $3,3 \%$ Customer Service & $24,1 \%$ SAP \\
\hline
\end{tabular}

Figure 12: Dynamic Sensitivity with High Priority of Training \& Support 
If the company is in a financial difficulty and the price is the most important factor in selecting the best software, Power BI will be by far the best alternative among others as illustrated in Figure 13.

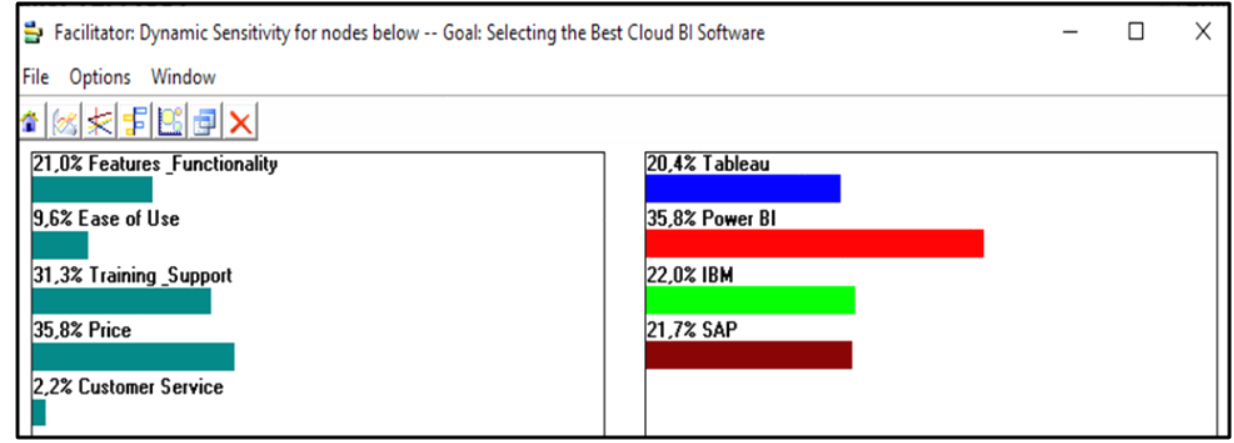

Figure 13: Dynamic Sensitivity with High Priority of Price

If the company wants to attach great importance to customer service and increase the weight of the criterion to $60 \%$, Tableau will be the alternative which needs to be selected as shown in Figure 14.

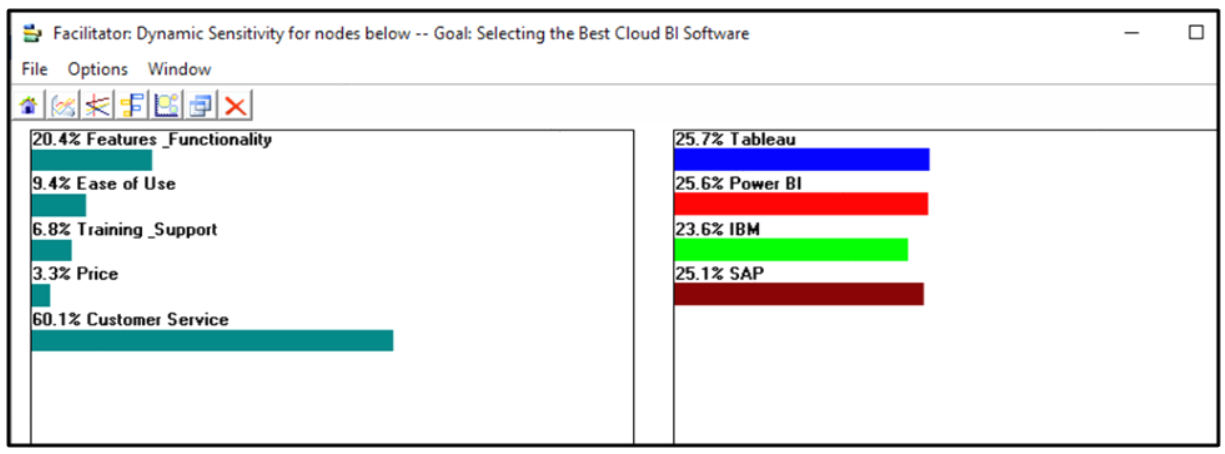

Figure 14: Dynamic Sensitivity with High Priority of Customer Service

\section{RESEARCH RESULTS}

There are many specifications offered by the software providers for cloud business intelligence. Every company can give different weights to them. In this project features \& functionality, training \& support, ease of use, customer service and price are selected by the company as criteria, and the analysis made relied on these specifications. Even add or drop among criteria can be possible in order to meet the changing needs, they are accepted as valid and inclusive for most organizations.

Analytical hierarchy process was used as a powerful method for multi-criteria decision making. AHP technique makes comparisons and gives the best alternative by comparing 
criteria weighted relatively between each other. In addition, this method offers an algorithm in order to check if your input is consistent. The software called Expert Choice, accepted as the leader in multi criteria decision making market, was used to make the best selection. After prioritizing the criteria and making comparisons in respect to relative importance of alternatives, the results were synthesized. The company should select the Power BI with 26,1 $\%$. It is the most appropriate software in terms of the criteria prioritized by the company including features \& functionality, training \& support, customer service, ease of use and price. Tableau is in the second place with $25,5 \%$ where IBM is on the third rank. The last is SAP with the lowest percentage. Even the percentages of the alternatives are close, Power BI will offer the optimum benefit when it is chosen.

After synthesizing the results, the organization may want to change priorities of the criteria. With the help of the analysis of dynamic sensitivity, the company can experience whether the best alternative changes or not when the priority of a criterion changes. When the company increase the priorities of criteria including "features \& functionality", "ease of use" and "price", the result will not change. As for the criteria of "training \& support" and "customer service", when the weights of these criteria are increased, the result will go in Tableau's favor. It is sensitive to the changes of weights. The result is affected when the priority for these criteria changes.

\section{CONCLUSION}

Business intelligence, which is the term arisen in 1950s, became prominent in recent years as a developed decision support system helping corporations to make faster, more accurate and insightful decisions. Many companies experienced this intelligence and enhanced the demand for business intelligence applications which are accepted as powerful ways to benefit from advantages like improving business process, becoming competitive, gaining accurate insights from the customer and so on. As the amount of data increases, it is getting difficult for companies to handle it. Therefore, the industry has started to look for new technologies to analyze data without the burden of centralized systems. Cloud computing is getting involved in this stage, which provides computing services such as databases, servers, storage, networking, software, analytics, and intelligence through the internet. Rather than storing files on a local storage device, using cloud-based storage for saving them is getting popular thanks to several advantages including speed, productivity, performance, security and efficiency. The feature of location independence makes data access and processing possible remotely.

The collaboration between business intelligence and cloud computing satisfies the needs and provides extra advantages. Even some of institutions concern about the cloud security and integration, many of them are pleasure with using this technology with enhanced 
security protocols and advantages from broad network access. The study is a valuable source for everyone who wants to learn business intelligence, cloud computing and the affiliation between them briefly. The terms and the subtitles associated with them presented in order for better understanding.

This study defends the concept of using cloud business intelligence for companies from small to big sized in order to become competitive. As time passed, new technologies and opportunities have been developed. Instead of adhering to old and strict rules, it is necessary to keep up with times and make use of all resources provided by new technologies as long as it is reliable and appropriate for businesses. With this consciousness a growing number of businesses will need to select a cloud business intelligence software and services offered in respect to its structure and needs.

In this study a decision support system was developed by applying the common methodology to the field not applied before in order to select the best software for the company. Analytical hierarchy process, which is one of the multi-criteria decision-making method, was involved in the selection of cloud business intelligence solution. The criteria and the alternatives were selected by the company in order to be used in AHP. A survey was made for prioritizing the criteria whose respondents are experts in information technology. The survey result showed us "features and functionality" is the most important factor for selecting the cloud business intelligence solution provided by companies whereas price is the least important factor affecting the result of the study. Therefore, price differences among alternatives have a little effect on decision making in this study. According to the survey results, the criteria was scaled in respect to priorities and the ratios of alternatives calculated for each criterion placed into the software called Expert Choice. After checking inconsistency ratio that should be less than 0,1 , the results were synthesized. I found that Power BI provides the best software as it best fits the company needs and objectives.

This study presents an example of selecting the best Cloud BI solution by using analytical hierarchical process, making several calculations over the alternatives chosen and the criteria prioritized. The application also can be adjustable for changing demands. If the company wants to change the priorities defined in the beginning of the project, we can reach the new result within a few seconds by making small adjustments. Cloud technology has started to shape our lives for a while. If the key to the future is hidden in cloud, moving business intelligence applications into cloud is the key to the success in the business world. 


\section{REFERENCES}
Capterra.
(2020).
11
23,
2020
tarihinde
Capterra:

https://www.capterra.com.au/compare/162441/176586/ibm-cognos-analytics/vs/powerbi?vs[] $=45527 \& v s[]=88726$ adresinden alınd 1

DOMO. (2020, 12 2). From Big Data to Better Decisions. https://www.domo.com/assets/downloads/15_biguide.pdf adresinden alınd 1

Elmalah, K., \& Nasr, M. M. (2019, 6 5). Cloud Business Intelligence. Int. J. Advanced Networking and Applications, 10(6).

Fast Company. (2021, 3 5). 3 5, 2021 tarihinde Fast Company: https://www.fastcompany.com/company/ibm adresinden alınd 1

IBM. (2020). Cognos Analytics Pricing. 112020 tarihinde https://www.ibm.com/products/cognosanalytics/pricing adresinden alınd 1

Microsoft Power BI. (2020). Power BI Pricing. 112020 tarihinde Microsoft Power BI: https://powerbi.microsoft.com/en-us/pricing/ adresinden alındı

Saaty, T. (2000). Fundementals of Decision Making and Priority Theory With the Analytic Hierarchy Process. 3 1, 2021 tarihinde https://books.google.com.tr/books?id=wct10TlbbIUC\&source=gbs_navlinks_s adresinden alındı

SAP. (2020). SAP Analytics Cloud for Business Intelligence. 112020 tarihinde https://www.sapstore.com/solutions/40117/SAP-Analytics-Cloud-for-Business-Intelligence adresinden alınd 1

Stellar Consulting. (2021, 3 6). Gartner 2020 Magic Quadrant for Analytics and BI platforms. 3 6, 2021 tarihinde https://stellarconsulting.co.nz/articles/gartner-2020-magic-quadrant-for-analyticsand-bi-platforms/ adresinden alındı

Tableau. (2020). Pricing for Data People. 112020 tarihinde https://www.tableau.com/pricing/teams-orgs adresinden alınd 1

Vargas, Ricardo. (2019). Analytical Hierarchy Process, Earned Value and Other Project Management Themes. 3 tarihinde https://rvdownloads.s3.amazonaws.com/uploads/downloads/books/ricardo_vargas_articles_c ompendium-third-edition.pdf adresinden alınd 1 